\title{
Risk factors for gastrointestinal parasite infections of dogs living around protected areas of the Atlantic Forest: implications for human and wildlife health
}

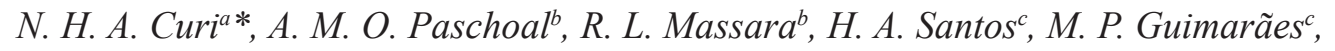 \\ M. Passamani and A. G. Chiarello ${ }^{d}$

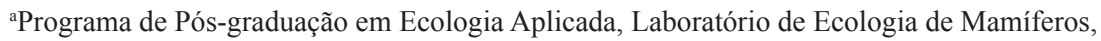 \\ Departamento de Biologia, Universidade Federal de Lavras - UFLA, Avenida Doutor Sylvio Menicucci, 1001, \\ Kennedy, CEP 37200-000, Lavras, MG, Brazil \\ 'Programa de Pós-graduação em Ecologia, Conservação e Manejo da Vida Selvagem, Departamento de Biologia, \\ Instituto de Ciências Biológicas, Universidade Federal de Minas Gerais - UFMG, Avenida Presidente Antônio Carlos, \\ 6627, Pampulha, CEP 31270-901, Belo Horizonte, MG, Brazil \\ 'Laboratório de Helmintologia, Departamento de Biologia, Instituto de Ciências Biológicas, \\ Universidade Federal de Minas Gerais - UFMG, Avenida Presidente Antônio Carlos, 6627, Pampulha, \\ CEP 31270-901, Belo Horizonte, MG, Brazil \\ ${ }^{d}$ Departamento de Biologia, Universidade de São Paulo - USP, Avenida Luigi Rosiello, s/n, Subsetor Oeste 11, \\ CEP 14051-090, Ribeirão Preto, SP, Brazil \\ *e-mail: nelsoncuri@hotmail.com
}

Received: November 17, 2015 - Accepted: March 1, 2016 - Distributed: May 31, 2017

(With 1 figure)

\begin{abstract}
Despite the ubiquity of domestic dogs, their role as zoonotic reservoirs and the large number of studies concerning parasites in urban dogs, rural areas in Brazil, especially those at the wildlife-domestic animal-human interface, have received little attention from scientists and public health managers. This paper reports a cross-sectional epidemiological survey of gastrointestinal parasites of rural dogs living in farms around Atlantic Forest fragments. Through standard parasitological methods (flotation and sedimentation), 13 parasite taxa (11 helminths and two protozoans) were found in feces samples from dogs. The most prevalent were the nematode Ancylostoma (47\%) followed by Toxocara (18\%) and Trichuris (8\%). Other less prevalent $(<2 \%)$ parasites found were Capillaria, Ascaridia, Spirocerca, Taeniidae, Acantocephala, Ascaris, Dipylidium caninum, Toxascaris, and the protozoans Cystoisospora and Eimeria. Mixed infections were found in 36\% of samples, mostly by Ancylostoma and Toxocara. Previous deworming had no association with infections, meaning that this preventive measure is being incorrectly performed by owners. Regarding risk factors, dogs younger than one year were more likely to be infected with Toxocara, and purebred dogs with Trichuris. The number of cats in the households was positively associated with Trichuris infection, while male dogs and low body scores were associated with mixed infections. The lack of associations with dog free-ranging behavior and access to forest or villages indicates that infections are mostly acquired around the households. The results highlight the risk of zoonotic and wildlife parasite infections from dogs and the need for monitoring and controlling parasites of domestic animals in human-wildlife interface areas.
\end{abstract}

Keywords: Canis familiaris, endoparasites, human-wildlife interface, zoonosis, protected areas.

\section{Fatores de risco para infecções parasitárias gastrointestinais em cães do entorno de áreas protegidas da Mata Atlântica: implicações para a saúde humana e da vida selvagem}

\section{Resumo}

Apesar da ubiquidade dos cães domésticos, de seu papel como reservatório de doenças, e do grande número de estudos sobre parasitas de cães urbanos, as áreas rurais no Brasil, especialmente aquelas na interface entre animais silvestres - animais domésticos - humanos, tem recebido pouca atenção de cientistas e gestores de saúde pública. Este artigo relata um estudo epidemiológico seccional de parasitas gastrointestinais de cães rurais em propriedades no entorno de fragmentos de Mata Atlântica. Através de métodos parasitológicos como flutuação e sedimentação, 13 táxons de parasitas (11 helmintos e dois protozoários) foram encontrados em amostras de fezes dos cães. O mais prevalente foi o nematóide Ancylostoma (47\%), seguido por Toxocara (18\%) e Trichuris (8\%). Outros parasitas menos prevalentes 
$(<2 \%)$ encontrados foram Capillaria, Ascaridia, Spirocerca, Taeniidae, Acantocephala, Ascaris, Dipylidium caninum, Toxascaris, e os protozoários Cystoisospora and Eimeria. Infecções mistas foram detectadas em $36 \%$ das amostras, a maioria por Ancylostoma e Toxocara. Vermifugações prévias não foram associadas a infecções, indicando que esta medida preventiva está sendo realizada incorretamente pelos proprietários. Com relação aos fatores de risco, cães com menos de um ano tiveram maior probabilidade de infecção por Toxocara, e os cães de raça pura por Trichuris. O número de gatos na propriedade foi associado positivamente com a infecção por Trichuris, enquanto cães machos e baixos escores corporais foram associados a infecções mistas. A ausência de associações com comportamento de vida livre e acesso a florestas ou vilas pelos cães indica que as infecções estão sendo predominantemente adquiridas nas propriedades. Os resultados destacam o risco de infecções parasitárias zoonóticas e para animais silvestres a partir dos cães, e a necessidade de monitorar e controlar os parasitas de animais domésticos em áreas de interface entre humanos e a vida selvagem.

Palavras-chave: Canis familiaris, endoparasitas, interface humanos-vida selvagem, zoonoses, áreas protegidas.

\section{Introduction}

Domestic dogs (Canis familiaris) are the most ubiquitous pets and the most abundant carnivore species worldwide (Young et al., 2011; Gompper, 2014). Of the almost one billion dogs living in the world today, more than a half is considered as rural dogs, i.e. free-ranging dogs that live in farms and small human settlements. These dogs are subsidized with food and shelter by humans, but frequently enter natural areas where they interact with wildlife, mostly with negative outcomes for the latter (Gompper, 2014). In Brazil there are estimates of five million rural dogs (Gompper, 2014). Recent studies indicated that these dogs are occupying the interior of protected areas at an alarming rate (Lacerda et al., 2009; Paschoal et al., 2012), and the vast array of ecological impacts of rural dogs to native communities, such as predation, interference competition and disease transmission (Butler et al., 2004; Vanak and Gompper, 2010; Gompper, 2014) are surely accompanying this ongoing biological invasion.

Such free-ranging behavior actually enhances parasite transmission between dogs, humans and wildlife (Knobel et al., 2014). There are about 360 pathogens that may infect dogs, many of them are zoonotic (Cleaveland et al., 2001), and almost half of the agents are shared with wildlife (Knobel et al., 2014). Moreover, dogs are frequently blamed for the maintenance and transmission of conservation-concern diseases to wild carnivores (Cleaveland et al., 2000; Acosta-Jamett et al., 2011; Woodroffe et al., 2012). Finally, because of their ubiquity, behavior and competency as hosts, dogs have been opportunely used as sentinels of infections for humans and wildlife around the world (Cleaveland et al., 2006; Salb et al., 2008).

Regarding gastrointestinal parasites, dogs are hosts for several species, including widespread parasites that affect humans such as the helminths Ancylostoma caninum and Toxocara canis (Dantas-Torres and Otranto, 2014). Hookworms (Ancylostoma sp.) causes cutaneous larva migrans and eosinophilic enteritis, and toxocariasis is a major health problem because infections often result in multisystemic disease by visceral migration and damage that may affect important organs, such as the eyes, liver and brain (McCarthy and Moore, 2000; Despommier, 2003). Protozoan intestinal infections cause diarrhea and weight loss, and increase susceptibility to other pathogens (McCarthy and Moore, 2000). However, studies reporting prevalence and associated risk factors of gastrointestinal parasites of dogs in Brazil are mostly restricted to urban areas (e.g. Oliveira-Sequeira et al., 2002; Balassiano et al., 2009; Klimpel et al., 2010; Heukelbach et al., 2012). Rural dogs, particularly those living around protected areas, i.e. domestic animal-human-wildlife interfaces, have received little scientific attention despite their potential role as reservoirs and sentinels for infections in these scenarios.

Thus, the aim of this study was to report on the prevalence of gastrointestinal parasites of rural dogs from six protected areas in the Atlantic Forest domain and to assess risk factors associated with the most prevalent and/or zoonotic parasite taxa and mixed infections. Infections are expected to be mostly associated with poor animal health management and dog's free-roaming habits. Finally, the results are discussed in the context of the zoonotic potential, and the conservation implications regarding the possibility of transmission to and from wildlife.

\section{Material and Methods}

Households with dogs, located at less than $2 \mathrm{~km}$ of the borders of six protected areas in the Atlantic Forest domain of the state of Minas Gerais, southeastern Brazil, were targeted for this study. These areas comprise three state parks, Serra do Brigadeiro (PESB), Rio Doce (PERD) and Sete Salões (PESS), and three private reserves, Fazenda Macedônia (RPPNFM), Feliciano Miguel Abdala (RPPNFMA), and Mata do Sossego (RPPNMS) (Figure 1). All of the areas had humans living in their vicinity and domestic dogs were recorded within their borders (Paschoal et al., 2012; Massara et al., 2015). The landscapes around the protected areas are composed of forest borders, small rural properties, their legal reserves and small human settlements. Most households apparently belong to low and median income families. Their dogs and cats are fed with human food leftovers and occasionally milk, meat, viscera, milk serum 


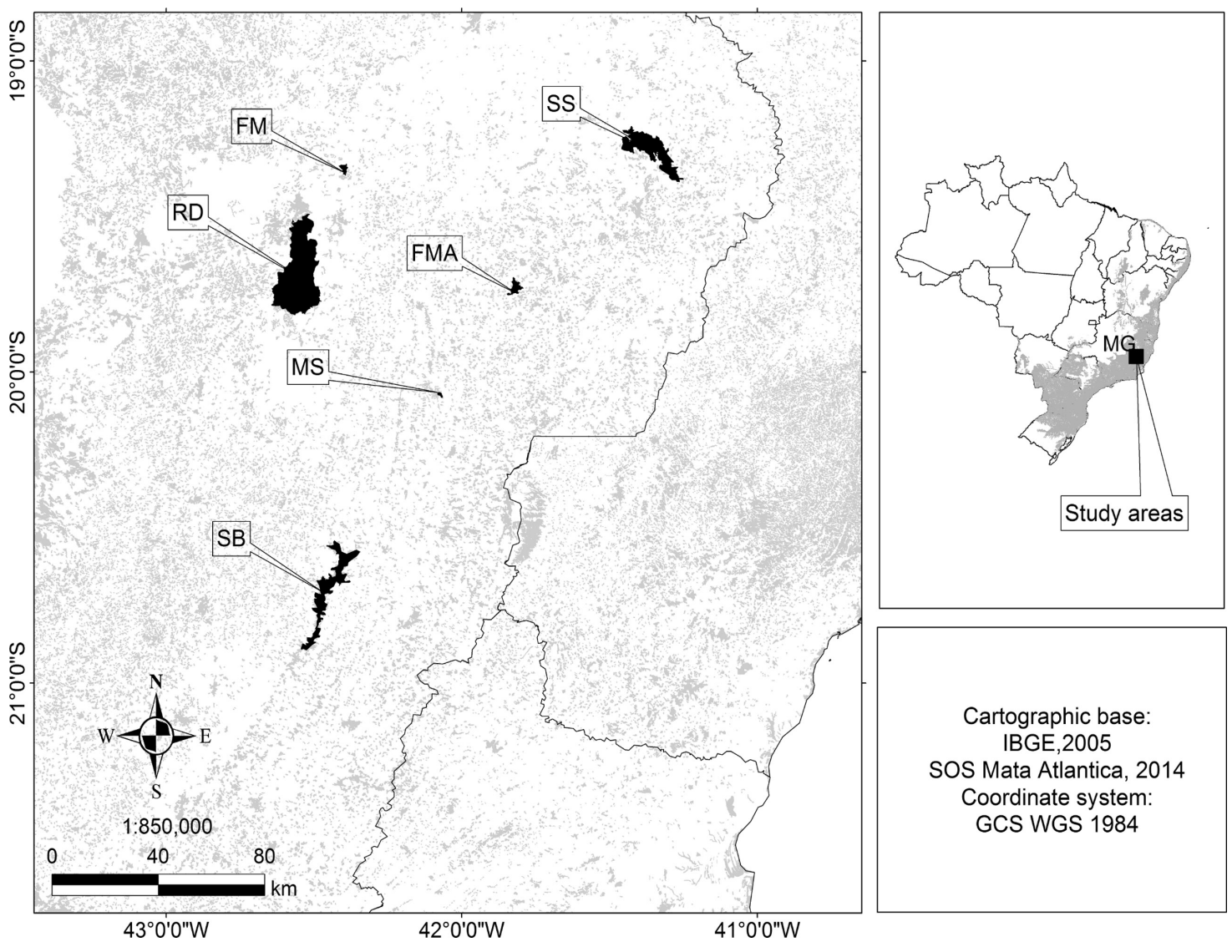

Figure 1. Location of the study areas in the Atlantic Forest domain of Minas Gerais State, Brazil (from Massara et al., 2015): Serra do Brigadeiro State Park (SB); Rio Doce State Park (RD); Sete Salões State Park (SS); Fazenda Macedônia Private Reserve (FM); Feliciano Miguel Abdala Private Reserve (FMA); Mata do Sossego Private Reserve (MS).

and commercial pet food. Most domestic animals owned do not receive any veterinary care.

Licenses from the State Forest Institute - IEF (UC: 080/10, 081/10 and 082/10) and approval from the Ethics Commission on Animal Use of Pontifícia Universidade Católica de Minas Gerais (CEUA PUC Minas 037/2010) were obtained prior to the field work. Animal manipulation procedures adhered to the recommendations from the COBEA (Brazilian College of Animal Experimentation) and the Animal Ethics Committee of FIOCRUZ (Oswaldo Cruz Institute Foundation) of the Brazilian Ministry of Health. After obtaining verbal approval of the house responsible for interviews and data collection, dogs were physically restrained and examined. Dog characteristics such as sex, age, age class (younger or older than one year), breed, weight, body score (from zero when extremely thin to five when extremely obese), sterilization and deworming status, presence of ectoparasites and clinical alterations were recorded in individual files for the dogs. For the households, the number of people, dogs (including those not sampled) and cats, whether dogs were kept free or not, and if they had access to adjacent forest or nearest villages, were recorded.
Feces samples were collected when present from the rectum of the examined dogs, stored in plastic tubes, identified, cooled up to five days, and sent to coproparasitological analysis. In the lab, samples were submitted to flotation and sedimentation methods. Samples were considered positive when at least one of the methods detected parasite eggs or protozoans. Parasite eggs or larvae were identified to the lower taxonomic level possible.

Prevalence comparisons were performed only for the most common parasite species. To assess differences in prevalence among the study areas, multiple Yates-corrected chi square tests were used. Differences in prevalence between genders, mixed breed and purebred, adults and puppies, and previously dewormed and untreated dogs were evaluated through binomial Yates-corrected chi square tests.

Multivariate logistic regressions were used to assess risk factors associated with infection with the most common parasite taxa and also for mixed infections (i.e. samples with two or more parasite taxa). Dog traits entered as binary (sex, breed, sterilization and deworming status, age class and the presence of ectoparasites) and continuous (age, body score and weight) explanatory variables. Household related explanatory variables were the numbers of people, dogs 
and cats (continuous), and mobility of dogs, access to forest and cities (binary). The level of significance was set at $95 \%(p<0.05)$ for all tests used. The Spearman's test was then used to detect correlations between significant variables. The STROBE statement (Von Elm et al., 2007) was used as a guide for the report of the data.

\section{Results}

One-hundred and twenty nine dogs (those which had feces in the rectum at the time of collection; other 194 dogs had no samples collectable) were sampled from 88 households. Households had from one to $15 \mathrm{dogs}$ (average $3.4 \pm 2.8$ dogs per household). Sex ratio was 2:1 (87 males and 42 females), $84.5 \%$ of dogs were mixed-breed, and $78.2 \%$ were adults (average age 35 months). Average weight was $13.4 \mathrm{~kg}$ (ranging from two to 81 ), and body score ranged from one to four, with an average of 2.1 . Only $3.8 \%$ were sterilized, and $42.6 \%$ of dogs were not previously dewormed. Most dogs (84.5\%) were kept without any space restriction, and $43 \%$ of dogs (in $44 \%$ of the households) share the peridomiciliary space with cats (numbers ranged from 0 to 18 with an average of one cat per household).

Thirteen parasite taxa (11 helminths and two protozoans) were found infecting $75 \mathrm{dogs}$, with an overall prevalence of $58 \%$ (ranging from 44 to $89.5 \%$ ). The most prevalent parasites were Ancylostoma sp., Toxocara sp. and Trichuris sp. (all with zoonotic potential), followed by other ten less prevalent parasites (Table 1). Mixed infections were detected in $27(36 \%)$ of positive samples. Of these, one sample had six parasite taxa $(3.7 \%)$, two with four taxa $(7.4 \%)$, five with three taxa $(18.5 \%)$, and 19 with two taxa (70.4\%). Associations between Ancylostoma and Toxocara occurred in 18 of the 27 mixed-infected dogs (66.6\%), between Ancylostoma and Trichuris in six (22.2\%), Ancylostoma, Toxocara and Trichuris in four (14.8\%), and between
Toxocara and Trichuris in the same last four cases. Mixed infections of protozoans and helminths occurred in three of four protozoan-positive samples.

Prevalence for Ancylostoma, Toxocara, and Trichuris were higher in RPPNFM and RPPNMS $(\mathrm{p}<0.05)$. No differences were found for the prevalence of any of the three parasites regarding sex or previous deworming $(\mathrm{p}>0.05)$. Differences in prevalence of Toxocara were detected between puppies and adults: younger dogs were more frequently infected $(\mathrm{p}=0.001)$. For Trichuris, purebred dogs were found to be more frequently infected $(\mathrm{p}=0.04)$.

The multivariate logistic regressions were significant for Toxocara $\left(\mathrm{p}=0.050 ; \mathrm{R}^{2}=24.8\right)$, Trichuris $(\mathrm{p}<0.0001$; $\left.\mathrm{R}^{2}=49.6\right)$ and for mixed infections $\left(\mathrm{p}=0.012 ; \mathrm{R}^{2}=29.9\right)$. Factors significantly associated with these infections (five from 15 variables entered the models) are listed in Table 2. There was autocorrelation solely between two variables included in the model for Trichuris: purebred and body score (Spearman coefficient $=0.1947, \mathrm{p}=0.026$ ). However both variables were retained in the model because of the low Spearman coefficient, lack of biological meaning, and because when the less significant variable (body score) was removed from the model the results were consistent for the other variables.

\section{Discussion}

The most prevalent dog parasite taxa found here (Ancylostoma, Toxocara and Trichuris) did not differ from other studies from urban areas in Brazil (Oliveira-Sequeira et al., 2002; Balassiano et al., 2009; Klimpel et al., 2010; Heukelbach et al., 2012). However, the other less common rural dog parasites found are quite different than those from Brazilian urban areas, probably due to the proximity with other host species, whether wild or domestic animals. The latter case is exemplified here by the finding of Eimeria, Ascaridia, and Ascaris,

Table 1. Prevalence of gastrointestinal parasites in dogs living around six Atlantic Forest fragments, Minas Gerais, Brazil.

\begin{tabular}{|c|c|c|c|c|c|c|c|c|}
\hline & & RPPNFM & PESB & PESS & RPPNFMA & RPPNMS & PERD & Total (\%) \\
\hline \multirow[t]{7}{*}{ Nematoda } & Ancylostoma & 11 & 10 & 10 & 9 & 16 & 5 & $61(47)$ \\
\hline & Toxocara & 3 & 4 & 5 & 0 & 10 & 2 & $24(18)$ \\
\hline & Trichuris & 2 & 0 & 2 & 3 & 2 & 1 & $10(8)$ \\
\hline & Ascaridia & 1 & 0 & 0 & 0 & 0 & 0 & $1(0.7)$ \\
\hline & Ascaris & 0 & 3 & 0 & 0 & 0 & 0 & $3(2)$ \\
\hline & Toxascaris & 0 & 0 & 0 & 1 & 0 & 0 & $1(0.7)$ \\
\hline & Spirocerca & 1 & 0 & 0 & 1 & 0 & 0 & $2(1.5)$ \\
\hline \multirow[t]{3}{*}{ Cestoda } & Taeniidae & 1 & 0 & 0 & 0 & 1 & 0 & $2(1.5)$ \\
\hline & $\begin{array}{l}\text { Dipylidium } \\
\text { caninum }\end{array}$ & 0 & 0 & 1 & 1 & 1 & 0 & $3(2)$ \\
\hline & Capillaria & 1 & 0 & 0 & 0 & 0 & 0 & $1(0.7)$ \\
\hline Acantocephala & Acantocephala & 0 & 1 & 0 & 0 & 1 & 0 & $2(1.5)$ \\
\hline \multirow[t]{4}{*}{ Protozoa } & Cystoisospora & 0 & 1 & 1 & 1 & 0 & 0 & $3(2)$ \\
\hline & Eimeria & 1 & 0 & 0 & 0 & 0 & 0 & $1(0.7)$ \\
\hline & Overall prevalence & $70.60 \%$ & $61.10 \%$ & $44.10 \%$ & $48.10 \%$ & $89.50 \%$ & $50.00 \%$ & $58.14 \%$ \\
\hline & Number of Taxa & 8 & 5 & 5 & 6 & 6 & 3 & 13 \\
\hline
\end{tabular}


Table 2. Significant factors for gastrointestinal parasitic infections of dogs living around six Atlantic Forest fragments, according to multivariate logistic regressions.

\begin{tabular}{lcccccc}
\hline \multicolumn{1}{c}{ Risk factors } & Coefficient & SE & Z & P value & Odds ratio & CI 95\% \\
\hline $\begin{array}{l}\text { Toxocara } \\
\text { Age class }\end{array}$ & -2.54 & 0.76 & -3.34 & 0.0008 & 0.0788 & $0.02-0.35$ \\
$\begin{array}{l}\text { Trichuris } \\
\text { Purebred }\end{array}$ & 5.51 & 2.44 & 2.26 & 0.0238 & 248.92 & $2.08-29,749.90$ \\
Number of cats & 1.64 & 0.55 & 2.97 & 0.0030 & 5.16 & $1.75-15.25$ \\
$\begin{array}{l}\text { Body score } \\
\text { Mixed infections }\end{array}$ & -3.67 & 1.65 & -2.22 & 0.0262 & 0.025 & $0.00-0.65$ \\
Sex (Males) & 1.34 & 0.62 & 2.16 & 0.0307 & 3.83 & $1.13-12.95$ \\
Body score & -1.42 & 0.64 & -2.21 & 0.0269 & 0.24 & $0.07-0.85$ \\
\hline
\end{tabular}

which are typical parasite genus of chickens and pigs (Vicente et al., 1997). Hence, these are probably accidental infections, since dogs frequently ingest viscera and feces of chickens, pigs and cats in these scenarios (author's personal observation). However, as dogs are implicated in the transmission of hookworms and Ascaris spp. (among other parasites) in rural areas (e.g. Traub et al., 2002), even those less prevalent parasites deserves attention when human populations are under risk.

The species richness found (13 taxa) is, for instance, similar to findings from urban and rural environments in Argentina (Fontanarrosa et al., 2006: 11 taxa; Soriano et al., 2010: 13 taxa), but is slightly higher than was found in Brazilian urban zones (Katagiri and Oliveira-Sequeira, 2008; Balassiano et al., 2009: eight taxa; Klimpel et al., 2010: five taxa) and rural areas (Santos et al., 2012: ten taxa). More profound studies on dog parasite communities are necessary to reveal differences in species distribution, richness and abundance patterns among urban, rural, and wildlife-rich areas in South America.

The high and widespread prevalence of gastrointestinal parasites, particularly the helminths Ancylostoma and Toxocara reveals a lack of preventive control of these dog populations, and that the risk of zoonotic diseases from dogs is strongly present in the study areas. The causes may be explained based on some factors cited in the papers of Katagiri and Oliveira-Sequeira (2008) and Balassiano et al. (2009): (1) unawareness of owners about the risks of acquiring zoonosis from their dogs and about prophylactic measures; (2) insufficient interactions between veterinarians and the rural people; (3) lack of governmental programs related to health and zoonosis in rural areas; (4) high environmental contamination due to the free-ranging behavior of dogs, and bad hygiene practices in some households leading to the accumulation of feces, organic matter, and maintenance and spread of parasite eggs. Contaminated soil is an important source of infections by gastrointestinal parasites, notably for Toxocara, Ascaris, Trichuris and Ancylostoma (Bethony et al., 2006; Tiyo et al., 2008).

The power of explanation of the logistic regressions showed that the set of factors explored explained from 25 to $50 \%$ of the correlations, and therefore should be considered as relevant. The lack of influence of gender on infection and the significantly high proportion of young dogs infected with Toxocara are in accordance with other studies (e.g. Fontanarrosa et al., 2006; Katagiri and Oliveira-Sequeira, 2008; Balassiano et al., 2009), but disagrees with the results of Heukelbach et al. (2012), who found that males were more infected with Toxocara. Purebred dogs are more likely to be infected with Trichuris, according to both chi-square tests and logistic regressions (with almost 250 times the chances), what is contrary to previous findings (Fontanarrosa et al., 2006; Balassiano et al., 2009). This may be linked to interactions between nutritional/immune status and the supposedly higher genetic variability and resistance to infection of mixed breed dogs, which may be more influent in rural environments, in this case, particularly for Trichuris infection.

Previous deworming was also non-influent in prevalence, contrary to findings from urban areas (e.g. Balassiano et al., 2009). This means that deworming is been incorrectly performed in these areas, and that intervention measures with anti-helminthic provision schemes and orientation to owners are urgently needed. However, consistent data on frequency, dose or products used by the owners could not be obtained.

According to the multivariate logistic regression analysis results, age class was negatively correlated to Toxocara infection, meaning that younger dogs are at higher risk of infection with this parasite, or that their developing immune system is not yet able to control or eliminate this parasite. This pattern seems consistent throughout the literature, including studies from South America (Oliveira-Sequeira et al., 2002; Fontanarrosa et al., 2006; Katagiri and Oliveira-Sequeira, 2008; Balassiano et al., 2009).

The number of cats influenced positively the presence of Trichuris, with dogs from houses with more cats having five-fold probability of infection. This parasite infects both cats and dogs (Dantas-Torres and Otranto, 2014). Therefore the more cats in a house, the more parasites are transmitted to dogs. The latter are probably contaminated via ingestion of cat feces.

Males were at least three times more likely to be co-infected with multiple parasite species, and this may 
be caused by the immunosuppressive testosterone activity and the vagrant behavior displayed by most male dogs. To the best of our knowledge, this observation has not been recorded in previous studies with dog parasites. Body scores influenced Trichuris sp. and mixed infections, but in a negative way. Lower body scores are more associated with multiple infections, probably because of nutritional status-immune system interactions. Variables associated with dog movements (space restriction, access to forests and cities) had no influence on parasitic infections, thus, contamination is probably happening at the peridomiciliary environment itself rather than during incursions of dogs to urban or forested areas.

Dogs are able to transmit macroparasites to wildlife (Knobel et al., 2014), and some of the parasite taxa reported here are able to infect wild mammals, especially carnivores. For instance, maned wolves (Chrysocyon brachyurus), crab-eating foxes (Cerdocyon thous), and sympatric domestic dogs were found to be infected with Ancylostoma, Trichuris and Toxocara in southeast Brazil (Curi et al., 2010, 2012; Santos et al., 2012). Toxocara sp. and hookworms may infect and cause disease in wild carnivores (Dunbar et al., 1994; Vieira et al., 2008). Vulnerable rare species of carnivores may also be affected, inclusive by the less prevalent species found in this study. As examples, the small wild felid Leopardus tigrinus may be a host for Trichuris sp. (Muniz-Pereira et al., 2009), and infections with acantocephalans, Taenia sp., Toxascaris sp., and Capillaria sp., among many other parasites, were already reported in Brazilian wild carnivores (Vieira et al., 2008; Curi et al., 2010). Although no data on parasites of wildlife in these areas were assessed, the strong presence of these free-ranging dogs inside these (Paschoal et al., 2012; Massara et al., 2015) and other fragments of the Atlantic Forest (Torres and Prado, 2010) is enough to warrant environmental fecal contamination and transmission to wildlife. Despite the high prevalence in all areas, attention and control measures should be prioritized on two areas: RPPNFM and RPPNMS, because people in surrounding rural settings and wildlife inside these small reserves may be at higher risk of infection with these canine parasites.

Concluding, the study embraces the "One Health" concept by linking human and animal health (Dantas-Torres and Otranto, 2014), and the results highlight the need for more investigation and the implementation of disease control measures in dogs from rural areas around forest fragments. These dogs are maintaining the infections in the peridomiciliary environment, and therefore may be responsible for the transmission of several parasites to humans and wildlife as well, and as sentinels, they are showing us that the risk of animal diseases and zoonosis is high in these areas. Risk factors detected in this study are somehow different from those studies in urban zones, showing that different control strategies should be applied to these environments. Finally, control measures directed to reservoir hosts may be effective to protect against wildlife diseases (Carter et al., 2009), and of course against zoonosis. Culling dogs is not recommended because it is almost always ineffective or creates unexpected (mostly bad) outcomes, and raises serious animal and human welfare issues (Carter et al., 2009; Knobel et al., 2014). Interventions with endoparasitic treatment should be accompanied by population control of hosts (i.e., dogs and cats) and reinforcement of responsible pet ownership (Torres and Prado, 2010), or population growth by increased fitness and reduced disease-related mortality may result in the emergence or persistence of other pathogens (Knobel et al., 2014), as well as in other negative effects of the presence of domestic animals in wildlife-rich areas such as the Atlantic Forest remnants.

\section{Acknowledgements}

The authors wish to thank to all owners involved and their dogs, to IEF (Instituto Estadual de Florestas) for licenses conceded and field support, to the staffs from the study areas, and to our funding agencies: CAPES (Coordenação de Aperfeiçoamento de Pessoal de Nível Superior) for scholarships, CNPQ (Conselho Nacional de Desenvolvimento Científico e Tecnológico, grant number 472802/2010-0), and FAPEMIG (Fundação de Amparo a Pesquisa do Estado de Minas Gerais, grant number APQ-01145-10, and sponsoring for the publication fee). Also thanks to Júlia Angélica Gonçalves Silveira, for her crucial comments on the manuscript. The sponsors had no role in the study design, in the collection, analysis and interpretation of data; in the writing of the manuscript; and in the decision to submit the manuscript for publication.

\section{References}

ACOSTA-JAMETT, G., CHALMERS, W.S.K., CUNNINGHAM, A.A., CLEAVELAND, S., HANDEL, I.G. and BRONSVOORT, B.M., 2011. Urban domestic dog populations as a source of canine distemper virus for wild carnivores in the Coquimbo region of Chile. Veterinary Microbiology, vol. 152, no. 3-4, pp. 247-257. http://dx.doi.org/10.1016/j.vetmic.2011.05.008. PMid:21641130.

BALASSIANO, B.C.C., CAMPOS, M.R., MENEZES, R.D.C.A.A. and PEREIRA, M.J.S., 2009. Factors associated with gastrointestinal parasite infection in dogs in Rio de Janeiro, Brazil. Preventive Veterinary Medicine, vol. 91, no. 2, pp. 234-240. http://dx.doi. org/10.1016/j.prevetmed.2009.05.030. PMid:19577316.

BETHONY, J., BROOKER, S., ALBONICO, M., GEIGER, S.M., LOUKAS, A., DIEMERT, D. and HOTEZ, P.J., 2006. Soil-transmitted helminth infections: ascariasis, trichuriasis, and hookworm. Lancet, vol. 367, no. 9521, pp. 1521-1532. http:// dx.doi.org/10.1016/S0140-6736(06)68653-4. PMid:16679166.

BUTLER, J.R.A., DU TOIT, J.T. and BINGHAM, J., 2004. Free-ranging domestic dogs (Canis familiaris) as predators and prey in rural Zimbabwe: threats of competition and disease to large wild carnivores. Biological Conservation, vol. 115, no. 3, pp. 369-378. http://dx.doi.org/10.1016/S0006-3207(03)00152-6.

CARTER, S.P., ROY, S.S., COWAN, D.P., MASSEI, G., SMITH, G.C., JI, W., ROSSI, S., WOODROFFE, R., WILSON, G.J. and DELAHAY, R.J., 2009. Options for the control of disease 2: targeting hosts. In: R.J. DELAHAY, G.C. SMITH and M.R. 
HUTCHINGS. Management of disease in wild mammals. Tokyo: Springer, pp. 121-146.

CLEAVELAND, S., APPEL, M.G.J., CHALMERS, W.S.K., CHILLINGWORTH, C., KAARE, M. and DYE, C., 2000. Serological and demographic evidence for domestic dogs as a source of canine distemper virus infection for Serengeti wildlife. Veterinary Microbiology, vol. 72, no. 3-4, pp. 217-227. http:// dx.doi.org/10.1016/S0378-1135(99)00207-2. PMid:10727832.

CLEAVELAND, S., LAURENSON, M.K. and TAYLOR, L.H., 2001. Diseases of humans and their domestic mammals: pathogen characteristics, host range and the risk of emergence. Philosophical Transactions of the Royal Society of London. Series B, Biological Sciences, vol. 356, no. 1411, pp. 991-999. http:// dx.doi.org/10.1098/rstb.2001.0889. PMid:11516377.

CLEAVELAND, S., MESLIN, F.X. and BREIMAN, R., 2006. Dogs can play useful role as sentinel hosts for disease. Nature, vol. 440, no. 7084, pp. 605. http://dx.doi.org/10.1038/440605b. PMid:16572146.

CURI, N.H.A., ARAÚJO, A.S., CAMPOS, F.S., LOBATO, Z.I.P., GENNARI, S.M., MARVULO, M.F.V., SILVA, J.C.R. and TALAMONI, S.A., 2010. Wild canids, domestic dogs and their pathogens in Southeast Brazil: disease threats for canid conservation. Biodiversity and Conservation, vol. 19, no. 12, pp. 3513-3524. http://dx.doi.org/10.1007/s10531-010-9911-0.

CURI, N.H.A., COELHO, C.M., MALTA, M.D.C.C., MAGNI, E.M.V., SÁBATO, M.A.L., ARAÚJO, A.S., LOBATO, Z.I.P., SANTOS, J.L.C., SANTOS, H.A., RAGOZO, A.A.M. and SOUZA, S.L.P., 2012. Pathogens of wild maned wolves (Chrysocyon brachyurus) in Brazil. Journal of Wildlife Diseases, vol. 48, no. 4, pp. 1052-1056. http://dx.doi.org/10.7589/2011-10-304. PMid:23060508.

DANTAS-TORRES, F. and OTRANTO, D., 2014. Dogs, cats, parasites, and humans in Brazil: opening the black box. Parasites \& Vectors, vol. 7, no. 1, pp. 22. http://dx.doi.org/10.1186/17563305-7-22. PMid:24423244.

DESPOMMIER, D., 2003. Toxocariasis: clinical aspects, epidemiology, medical ecology, and molecular aspects. Clinical Microbiology Reviews, vol. 16, no. 2, pp. 265-272. http://dx.doi. org/10.1128/CMR.16.2.265-272.2003. PMid:12692098.

DUNBAR, M.R., MCLAUGHLIN, G.S., MURPHY, D.M. and CUNNINGHAM, M.W., 1994. Pathogenicity of the hookworm, Ancylostoma pluridentatum, in a Florida panther (Felis concolor coryi) kitten. Journal of Wildlife Diseases, vol. 30, no. 4, pp. 548551. http://dx.doi.org/10.7589/0090-3558-30.4.548. PMid:7760486.

FONTANARROSA, M.F., VEZZANI, D., BASABE, J. and EIRAS, D.F., 2006. An epidemiological study of gastrointestinal parasites of dogs from Southern Greater Buenos Aires (Argentina): age, gender, breed, mixed infections, and seasonal and spatial patterns. Veterinary Parasitology, vol. 136, no. 3-4, pp. 283-295. http://dx.doi.org/10.1016/j.vetpar.2005.11.012. PMid:16364551.

GOMPPER, M.E., 2014. Free-ranging dogs and wildlife conservation. Oxford: Oxford University Press.

HEUKELBACH, J., FRANK, R., ARIZA, L., LOPES, Í.S., SILVA, A.D.A., BORGES, A.C., LIMONGI, J.E., ALENCAR, C.H.M. and KLIMPEL, S., 2012. High prevalence of intestinal infections and ectoparasites in dogs, Minas Gerais State (southeast Brazil). Parasitology Research, vol. 111, no. 5, pp. 1913-1921. http://dx.doi.org/10.1007/s00436-012-3037-0. PMid:22825284.
KATAGIRI, S. and OLIVEIRA-SEQUEIRA, T.C.G., 2008. Prevalence of dog intestinal parasites and risk perception of zoonotic infection by dog owners in São Paulo State, Brazil. Zoonoses and Public Health, vol. 55, no. 8-10, pp. 406-413. http:// dx.doi.org/10.1111/j.1863-2378.2008.01163.x. PMid:18811905.

KLIMPEL, S., HEUKELBACH, J., POTHMANN, D. and RÜCKERT, S., 2010. Gastrointestinal and ectoparasites from urban stray dogs in Fortaleza (Brazil): high infection risk for humans? Parasitology Research, vol. 107, no. 3, pp. 713-719. http://dx.doi.org/10.1007/s00436-010-1926-7. PMid:20532563.

KNOBEL, D.L., BUTLER, J.R., LEMBO, T., CRITCHLOW, R. and GOMPPER, M.E., 2014. Dogs, disease, and wildlife. In: M.E. GOMPPER. Free-ranging dogs and wildlife conservation. Oxford: Oxford University Press, pp. 144-169.

LACERDA, A.C.R., TOMAS, W.M. and MARINHO-FILHO, J., 2009. Domestic dogs as an edge effect in the Brasília National Park, Brazil: interactions with native mammals. Animal Conservation, vol. 12 , no. 5, pp. 477-487. http://dx.doi.org/10.1111/j.14691795.2009.00277.x.

MASSARA, R.L., PASCHOAL, A.M.O., DOHERTY JUNIOR, P.F., HIRSCH, A. and CHIARELLO, A.G., 2015. Ocelot population status in protected Brazilian Atlantic Forest. PLoS One, vol. 10, no. 11, pp. e0141333. http://dx.doi.org/10.1371/journal. pone.0141333. PMid:26560347.

MCCARTHY, J. and MOORE, T.A., 2000. Emerging helminth zoonoses. International Journal for Parasitology, vol. 30, no. 12-13, pp. 1351-1359. http://dx.doi.org/10.1016/S0020-7519(00)001223. PMid: 11113260.

MUNIZ-PEREIRA, L.C., VIEIRA, F.M. and LUQUE, J.L., 2009. Checklist of helminth parasites of threatened vertebrate species from Brazil. Zootaxa, vol. 2123, pp. 1-45.

OLIVEIRA-SEQUEIRA, T.C.G., AMARANTE, A.F.T., FERRARI, T.B. and NUNES, L.C., 2002. Prevalence of intestinal parasites in dogs from São Paulo State, Brazil. Veterinary Parasitology, vol. 103, no. 1-2, pp. 19-27. http://dx.doi.org/10.1016/S03044017(01)00575-1. PMid:11750997.

PASCHOAL, A.M., MASSARA, R.L., SANTOS, J.L. and CHIARELLO, A.G., 2012. Is the domestic dog becoming an abundant species in the Atlantic Forest? A study case in southeastern Brazil. Mammalia, vol. 76, no. 1, pp. 67-76. http:// dx.doi.org/10.1515/mammalia-2012-0501.

SALB, A.L., BARKEMA, H.W., ELKIN, B.T., THOMPSON, R.A., WHITESIDE, D.P., BLACK, S.R., DUBEY, J.P. and KUTZ, S.J., 2008. Dogs as sources and sentinels of parasites in humans and wildlife, northern Canada. Emerging Infectious Diseases, vol. 14, no. 1, pp. 60-63. http://dx.doi.org/10.3201/eid1401.071113. PMid: 18258078

SANTOS, J.L.C., MAGALHÃES, N.B., SANTOS, H.A.D., RIBEIRO, R.R. and GUIMARÃES, M.P., 2012. Parasites of domestic and wild canids in the region of Serra do Cipó National Park, Brazil. Revista Brasileira de Parasitologia Veterinária, vol. 21, no. 3, pp. 270-277. http://dx.doi.org/10.1590/S198429612012000300016. PMid:23070438.

SORIANO, S.V., PIERANGELI, N.B., ROCCIA, I., BERGAGNA, H.F.J., LAZZARINI, L.E., CELESCINCO, A., SAIZ, M.S., KOSSMAN, A., CONTRERAS, P.A., ARIAS, C. and BASUALDO, J.A., 2010. A wide diversity of zoonotic intestinal parasites infects urban and rural dogs in Neuquén, Patagonia, Argentina. Veterinary Parasitology, vol. 167, no. 1, pp. 81-85. http://dx.doi. org/10.1016/j.vetpar.2009.09.048. PMid:19864068. 
TIYO, R., GUEDES, T.A., FALAVIGNA, D.L.M. and FALAVIGNAGUILHERME, A.L., 2008. Seasonal contamination of public squares and lawns by parasites with zoonotic potential in southern Brazil. Journal of Helminthology, vol. 82, no. 1, pp. 1-6. http:// dx.doi.org/10.1017/S0022149X07870829. PMid:18053297.

TORRES, P.C. and PRADO, P.I., 2010. Domestic dogs in a fragmented landscape in the Brazilian Atlantic Forest: abundance, habitat use and caring by owners. Brazilian Journal of Biology = Revista Brasileira de Biologia, vol. 70, no. 4, pp. 987-994. http:// dx.doi.org/10.1590/S1519-69842010000500010. PMid:21180903.

TRAUB, R.J., ROBERTSON, I.D., IRWIN, P., MENCKE, N. and THOMPSON, R.A., 2002. The role of dogs in transmission of gastrointestinal parasites in a remote tea-growing community in northeastern India. The American Journal of Tropical Medicine and Hygiene, vol. 67, no. 5, pp. 539-545. PMid:12479559.

VANAK, A.T. and GOMPPER, M.E., 2010. Interference competition at the landscape level: the effect of free-ranging dogs on a native mesocarnivore. Journal of Applied Ecology, vol. 47, no. 6, pp. 1225-1232. http://dx.doi.org/10.1111/j.1365-2664.2010.01870.x.

VICENTE, J.J., RODRIGUES, H.D.O., GOMES, D.C. and PINTO, R.M., 1997. Brazilian nematodes. Part V: nematodes of mammals. Revista Brasileira de Zoologia = Zoologia, vol. 14, pp. 1-452.
VIEIRA, F.M., LUQUE, J.L. and MUNIZ-PEREIRA, L.C., 2008. Checklist of helminth parasites in wild carnivore mammals from Brazil. Zootaxa, vol. 1721, pp. 1-23.

VON ELM, E., ALTMAN, D.G., EGGER, M., POCOCK, S.J., GØTZSCHE, P.C. and VANDENBROUCKE, J.P., 2007. The strengthening the reporting of observational studies in epidemiology (STROBE) statement: guidelines for reporting observational studies. Bulletin of the World Health Organization, vol. 85, no. 11, pp. 867-872. http://dx.doi.org/10.2471/BLT.07.045120. PMid:18038077.

WOODROFFE, R., PRAGER, K.C., MUNSON, L., CONRAD, P.A., DUBOVI, E.J. and MAZET, J.A., 2012. Contact with domestic dogs increases pathogen exposure in endangered African wild dogs (Lycaon pictus). PLoS One, vol. 7, no. 1, pp. e30099. http://dx.doi.org/10.1371/journal.pone.0030099. PMid:22238695.

YOUNG, J.K., OLSON, K.A., READING, R.P., AMGALANBAATAR, S. and BERGER, J., 2011. Is wildlife going to the dogs? Impacts of feral and free-roaming dogs on wildlife populations. Bioscience, vol. 61, no. 2, pp. 125-132. http://dx.doi.org/10.1525/bio.2011.61.2.7. 